\author{
Markova T. \\ Ph.D., Associate Professor \\ Department of Accounting and Auditing \\ E-mail: markova.tetiana17@gmail.com \\ ORCID ID: 0000-0002-9437-2635 \\ Pchelianska G. \\ Assistant \\ Department of Accounting and Auditing \\ E-mail: gaya_od@ukr.net \\ ORCID ID: 0000-0003-0944-986X
}

\author{
Melnyk Yu. \\ Doctor of Economics, Professor \\ Department of Accounting and Auditing \\ E-mail: 9701080@ukr.net \\ ORCID ID: 0000-0003-2307-1592 \\ Tilloyev S. \\ The student of the firth grade of Economy, Business \\ and Control Faculty \\ Odessa National Academy of Food Technologies \\ Kanatna str., 112, Odesa, Ukraine, 65039 \\ E-mail: tilloievsanzhar@ukr.net \\ ORCID ID: 0000-0002-3340-121X
}

\title{
FEATURES OF MANAGEMENT INFORMATION SYSTEMS AND TECHNOLOGIES IN THE ORGANIZATION OF THE AUTOMATED ACCOUNTING AND ANALYTICAL PROCESS AT THE ENTERPRISE
}

The article substantiates the role of information systems and technologies in the management of accounting and analytical process at the enterprise. The advantages and disadvantages of using information systems and technologies have been listed. It has been determined that the observance of the quality of information support is possible under the condition of observance of the principles of systematization, complexity, scientificity, reliability, expediency, efficiency, priority, transparency and target direction. Applied programs of domestic and foreign accounting experience have been given. An assessment of the use of computers at the enterprise and the use of the Internet in Ukraine have been carried out. After analyzing the use of the Internet, it was determined that since 2010 to the present, the share is growing accordingly. And the Internet is mostly used to send or receive e-mails (70,65\%-98,84\%), receive information about goods and services $(44,52 \%-89,22)$, make banking operations $(81,53 \%-97,65 \%)$. A study of the number of companies that used computers by industry found that the largest number of companies are manufacturing and wholesale and retail ones.

Key words: information systems and technologies, automated workplace, accounting, analysis, enterprise.

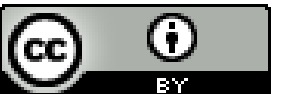

This work is licensed under a Creative Commons Attribution 4.0 International License http://creativecommons.org/licenses/by/4.0/
Statement of the problem and its connection with important scientific and practical tasks. Information support of the management accounting system always depends on the requirements, which are accompanied by constant changes in the external environment, socio-economic conditions, interdependence and cooperation with other information management systems of the enterprise. And one of the effective and efficient solutions to ensure the collection, processing and transmission of large arrays of databases is the computerization of the accounting and analytical process in the enterprise.

The complexity of enterprise management, the growth of technological equipment and the intensification of competition are associated with the emergence of new risks for enterprises, which increases the requirements for the quality of management. Effective and efficient management of the enterprise in today's market conditions is impossible without information technology.

In recent years, domestic and foreign scientists in the field of accounting in the categorical-conceptual apparatus of accounting science began to introduce new concepts that characterize new phenomena or individual elements that stand out in their composition. One of such concepts is "accounting information space", which characterizes a certain structured and organized information environment to ensure the specific goals of management decision-makers [1]. According to prof. E. Sidorova, the main reason for the existence of such a situation is that at the end of the twentieth century the direction of research in the field of information technology has shifted towards building a single information space [2, p. 176]. The defining prerequisite for such changes was the rapid development of information and communication technologies, total informatization and computerization of enterprises, free and relatively cheap access to the Internet, the emergence and introduction of cloud technologies, modern technologies for remote access, etc., which allowed faster processing of accounting information, improving the means and technologies of its storage and improving information interaction with internal and external users.

Management decisions in conditions of uncertainty of the external environment should be based on accurate calculations, deep and comprehensive economic analysis and forecasting. The costs of the enterprise, 
contractual conditions with contractors, the amount of receivables and payables should be subject to daily research, as a result of which it will be possible to identify and form reserves for their further use. Recently, more and more attention has been paid to improving the information base of the business management system.

The analysis of the latest publications on the problem. Research of the state and problems of organization and accounting at the enterprise with the help of automated information systems was carried out by such domestic scientists as F.F. Butynets, M.T. Bilukha, V.P. Zavgorodniy, R.M. Zakharchenko, M.V. Karamushka and T.G. Kiryushatova, M.S. Pushkar, V.V. Sopko, V.Ye. Khodakov, M. G. Chumachenko and others. Note that O.S. Vysochan, A.G. Zagorodniy, V.D. Shkvir in their works study local and modern hybrid information systems, which are the basis for the creation of information systems for accounting. Peculiarities and importance of the use of information and communication technologies in accounting and reporting have been studied by such scientists as: K.L. Bagriy, S.V. Ivakhnenkov, A.S. Krutova, V.O. Osmyatchenko, M.M. Matyukha. All of them have made a significant contribution to the study of the genesis and use of accounting information systems. However, some issues regarding the effective implementation and use of information systems in domestic enterprises are still incompletely explored, given the new challenges of a market economy.

Forming of the aims of the research. The purpose of this study is to substantiate the organization of the accounting and analytical process with the use of information technology, analysis of applied programs of do- mestic and international experience in accounting.

Giving an account of the main results and their substantiation. The most well-known information system that meets the needs of management is the management accounting and analytical system. The information obtained from the use of this system reflects the production capacity, taking into account the financial capabilities of the entity. The formation of the accounting and analytical system is the creation of a cross-cutting economic system with the help of the appropriate reference and information fund based on databases, which is used to form a system of analytical indicators-tools for operational, tactical and strategic management decisions.

Analysis of the practice of Ukrainian enterprises gives grounds to determine that the non-use of the necessary software of the accounting and analytical process leads to the fact that organizations generate unreliable financial results due to technical errors. And this leads to the fact that it is difficult for organizations to navigate in the further development of activities, maintaining solvency and financial stability.

We should note that the quality of accounting information is the key to determining the most optimal and effective management decisions that are aimed at reducing resource costs, increasing profits and market value of the enterprise.

Adherence to the quality of information support is possible provided that such principles as systematization, complexity, scientificity, reliability, expediency, efficiency, priority, transparency and targeting are observed. The content of the principles is presented in Fig. 1.

\begin{tabular}{|c|c|}
\hline \multicolumn{2}{|c|}{ PRINCIPLES OF ACCOUNTING SECURITY FOR MANAGEMENT DECISIONS ACCEPTANCE } \\
\hline $\begin{array}{l}\text { The principle of } \\
\text { transparency }\end{array}$ & $\begin{array}{l}\text { accessibility, comprehensibility, clarity, openness of the facts and parameters form- } \\
\text { ing information support environment }\end{array}$ \\
\hline $\begin{array}{l}\text { The principle of } \\
\text { systematization }\end{array}$ & $\begin{array}{l}\text { study of structural elements of input information as complex systems with a certain } \\
\text { structural and functional structure in the relationship of their components }\end{array}$ \\
\hline $\begin{array}{l}\text { The principle of } \\
\text { complexity }\end{array}$ & $\begin{array}{l}\text { evaluation of structural elements of input information in unity, their change and de- } \\
\text { velopment in quantitative and qualitative signs }\end{array}$ \\
\hline $\begin{array}{l}\text { The principle of } \\
\text { scientificity }\end{array}$ & $\begin{array}{l}\text { comprehensive study of the influence of objective factors on formation of input pa- } \\
\text { rameters of information providing, application of scientific methods of analytical }\end{array}$ \\
\hline $\begin{array}{l}\text { The principle of } \\
\text { reliability }\end{array}$ & ensuring results as close as possible to the real ones \\
\hline $\begin{array}{l}\text { The principle of } \\
\text { expediency }\end{array}$ & $\begin{array}{l}\text { establishing the optimal ratio between the purpose of the study and methods of its } \\
\text { implementation, primarily through the formation of appropriate information support }\end{array}$ \\
\hline $\begin{array}{l}\text { The principle of } \\
\text { efficiency }\end{array}$ & $\begin{array}{l}\text { achieving the highest results at the lowest cost (low level of labor, the cost of input } \\
\text { processing software, etc.) }\end{array}$ \\
\hline $\begin{array}{l}\text { The principle of } \\
\text { priority }\end{array}$ & $\begin{array}{l}\text { identification of priorities in achieving the goal, the selection of primary and sec- } \\
\text { ondary in importance and sequence of stages of formation of information support }\end{array}$ \\
\hline $\begin{array}{l}\text { The principle of } \\
\text { target direction }\end{array}$ & $\begin{array}{l}\text { participation in the process of forming information support for a wide range of } \\
\text { stakeholders }\end{array}$ \\
\hline
\end{tabular}

Fig. 1 - Principles of accounting security for management decisions [3] 
The structure of the information base in making management decisions is based on several data sets. $80 \%$ of the required information is accumulated and formed in the accounting and reporting system.

- The place of accounting in the information support of management activities is determined by various organizational and legal forms and the complexity of the organizational structure. To increase the efficiency of management decisions, we can identify the main areas of its use:

- control - to ensure the accuracy of financial information about the activities of the enterprise;

- assessment - to assess past and future events;

- planning - obtaining information about qualitative and quantitative indicators, as well as the im- pact on the organization, the use of this information as a basis for planning [4].

The 21 st century is an era of the latest information and communication technologies and democratization and socialization of governance. The introduction of computer technology and the Internet in the daily processes of enterprises is due to the spread and the need to process huge amounts of information in the shortest possible time and its instantaneous transmission over long distances. Such innovations change modern methods of doing business, reformat the management structure and organizational design of enterprises, and at the same time, generate unique competitive advantages for enterprises [5]. The advantages and disadvantages of information technology are systematized in table. 1 .

Table 1

\section{Advantages and disadvantages of using automated information systems for accounting}

\section{by domestic enterprises *}

\begin{tabular}{|c|c|}
\hline Advantages & Disadvantages \\
\hline $\begin{array}{l}\text { From an economic point of view, information and } \\
\text { communication technologies have the advantage of } \\
\text { being seen as a means of production that can freely } \\
\text { replace the personnel of the enterprise. }\end{array}$ & $\begin{array}{l}\text { Information and communication technologies (ICT) can lead } \\
\text { to a decrease in the number of middle managers and employ- } \\
\text { ees }\end{array}$ \\
\hline $\begin{array}{l}\text { Modern information and communication technolo- } \\
\text { gies also reduce the cost of production due to lower } \\
\text { operating costs. }\end{array}$ & $\begin{array}{l}\text { Automatically change the organizational structure of enter- } \\
\text { prise management, the hierarchy of decision-making, reduce } \\
\text { the cost of acquiring information and expand the possibilities } \\
\text { of its use. }\end{array}$ \\
\hline Internet access & Large investments \\
\hline Streamlining accounting & Long-term system design \\
\hline Reducing the number of errors & Excessively centralized information processing \\
\hline $\begin{array}{l}\text { Improving the quality and reliability of regulatory } \\
\text { information }\end{array}$ & \multirow{2}{*}{$\begin{array}{l}\text { Technical impossibility and / or economic inefficiency of au- } \\
\text { tomation and computerization of management functions, } \\
\text { which do not allow direct access of employees to the database }\end{array}$} \\
\hline \multirow{2}{*}{ Timely diagnosis of problems } & \\
\hline & The constant need to adapt to modern times. \\
\hline
\end{tabular}

*Compiled by the authors

Improving the efficiency of the enterprise as a whole is an expectation from the introduction of accounting and analytical and information system, which will address a number of issues such as: improving the system of cooperation with suppliers, reducing product shortages, accounting and cash management, inventory management at the enterprise, etc.

There is a growing interdependence between business strategy, rules and procedures, on the one hand, and information systems software, databases and digital data transmission, on the other. A change in one of these components often leads to changes in other components. This relationship becomes critical when developing strategic plans for the future. Increasing market share, moving towards improving the quality or reducing the cost of services while increasing employee productivity increasingly depend on the types and quality of modern information and communication technologies in the enterprise.

Thus, if there are changes in information technology in the enterprise, these changes affect other com- ponents of activity. There may be personnel changes, changes in working methods, transformation of the organizational structure. Information and communication technologies can be a powerful impetus for launching more competitive and optimal and effective management models in the enterprise.

The costs of implementing information technology are not only recouped, but also profitable. Large Western corporations spend on information systems from 1,5 to $4 \%$ of their annual turnover, which per employee is from 3 to 12 thousand US dollars. The return on investment in information technology reaches $80 \%$ [6].

Thus, information technology and systems have revolutionized firms and industries, becoming the largest component of capital investment in the United States and many industrialized societies. For example, in the United States, capital investment in information technology, defined as hardware, software, and communications equipment, increased from $34 \%$ to $50 \%$ between 1980 and 2004 [7]. 
Information technology expands the possibilities of effective management, as it provides managers, financiers, enterprise managers of all ranks with the latest methods of processing and analysis of economic information needed to make optimal decisions, which increases the competitiveness of the enterprise as a whole and its staff and products [6].

Information technology is crucial in business management and is an essential factor in its success. The application of information technology for business management requires inductive thinking - the ability to first see an effective solution, and then look for problems to which it is applied. Timeliness and quality of management functions are realized in the market in the form of profit. Given the rapid change of information technology and the emergence of new ones, the modern leader must constantly study new technologies, understand their significance, identify areas of application, distribute these areas within the firm and develop implementation plans. Therefore, professionals who will be able to perform these works before the technology becomes available, will contribute to the company's efforts to move forward in the fierce competition.

An essential component of market conditions is information systems that penetrate all business functions and effectively connect them. The use of information systems by firms and organizations shows the degree of modern training of their administration and management. In the process of management information about the state of the system, is received as well as the result (achievement or failure) of the task in order to make adjustments and influence the system and ensure the implementation of optimal management tasks. All types of information needed for management are an information system. The management system and the information system at any level of management form a synergy.

Management is impossible without information data. The decision-making process, according to G. Simon, has three stages: information, design, choice. At the information stage, the environment is explored, events and conditions that require decision-making are identified. At the project stage, possible directions of activity (alternatives) are developed and evaluated. At the selection stage, a certain alternative is substantiated and selected, organizing monitoring (monitoring) of its implementation. The individual stages of the process can be repeated many times if the manager is not satisfied with the information collected or the results of its processing. Each stage has its own unique requirements. At the information stage, managers receive from information systems information about the work of the organization, which can motivate decision-making. For example, market research results and a review of external databases may provide information about changes in a firm's competitiveness. At the project stage, the manager must find out whether the situation that requires a decision is programmable or unprogrammed, ie it is structured or not.

Information systems are transforming businesses, and the visible results are an increase in the use of cell phones and wireless telecommunications devices, a significant shift to news and information on the Internet, the rapid development of e-commerce and advertising on the Internet, and new security and accounting laws that solve problems, raised by the exponential growth of digital information. The Internet has also drastically reduced the costs of businesses operating globally. These changes have led to the emergence of a digital firm, a firm in which:

- Most of the firm's significant business relationships with customers, suppliers and employees are provided digitally and mediated.

- Basic business processes, or logically related business tasks, are carried out using digital networks.

- Key corporate assets (intellectual property, core competencies, financial and human assets) are managed by digital means.

- Business response to changes in the environment is enhanced by digital communications, which allows you to change the time (business is conducted around the clock and without days off) and move space (business is conducted around the world or outside the traditional geographical boundaries).

Information systems are needed to conduct dayto-day business in the United States and most other developed countries, as well as to achieve strategic business goals. Some companies, such as Amazon and E*Trade, would not exist without information systems. Some services, such as finance, insurance and real estate, could not operate without information systems. The firm's ability to use IT becomes intertwined with the firm's ability to implement corporate strategy [7].

Business companies invest heavily in information systems to achieve six effective and strategic business goals:

1) Operational excellence: Efficiency, productivity and improvement of changes in business practice and behavior of managers.

2) New products, services and business models: A business model describes how a company produces, supplies and sells goods or services to create wealth. Information systems and technologies create opportunities for products, services and new ways of doing business.

3) Confidentiality of customers and suppliers: improved communication with clients and customer service increases revenue, and improved communication with suppliers reduces costs.

4) Improved decision-making: without accurate and timely information, business leaders must make decisions based on forecasts, best assumptions and luck - a process that leads to overproduction and underdevelopment of goods, increased costs and loss of customers.

5) Competitive Advantage: Implementing efficient and effective information systems can allow a company to take less for great products, increasing sales and profits in comparison with their competitors.

6) Survival: Information systems can also be a necessity of doing business. The need may be due to changes at the industry level, as in the introduction of ATMs in the retail banking industry. The need may also be due to government regulations that require the company to store data and provide specific information.

It should be noted that in Ukraine there are 
a significant number of software products for accounting automation, namely "MASTER: Accounting", "Sail", "MEDoc", "Fin Expert", "Finance without problems", "Lady Fan", "1C: Accounting Prof. 6.0 for Windows "," 1C: Accounting 7.7 for Ukraine "," Clerk ". We should note that, as a rule, the following areas of the accounting system are subject to automation: a single information space, personnel accounting, accounting for labor and its payment, accounting for sales of goods (works, services), budgeting, financial management, inventory accounting, accounting for goods (works, services), automation of cost calculation, reporting of enterprises.

The use of modern computer information systems and technologies is becoming increasingly important in the management of accounting and analytical process in the enterprise, as it requires modern time requirements and has significant advantages. Today, there are many examples worldwide of the relationship between information and communication technologies (ICTs) and economic growth and development. Countries with high levels of economic development also show high rates of ICT penetration. It should be noted that private sector enterprises and business in general have bene- fited more from the fruits of the information revolution. There is no doubt that growth in ICT infrastructure and human resources has provided countries with rapid growth and transformed them into powerful economies in the information society. The use of information systems and technologies in the management of the business structure is carried out, in particular, for the purpose of efficient and operational computer processing of information resources, storage of large amounts of incoming and accounting-analytical and economically important information and its transmission over an unlimited distance. That is, the main task is to optimize the management accounting of economic activity of the enterprise based on the use of information systems and technologies. Thus, the assessment of the use of information systems and technologies in enterprise management during the existence and operation of the fourth industrial revolution is relevant.

Thus, statistical studies (Table 2) show that the share of enterprises that have used computers in their activities for almost 20 years in Ukraine, as a percentage of the total number of enterprises that participated in the survey is in the range of $87,7-95,4 \%$.

Table 2

Assessment of the use of computers at the enterprise and directions of use of the Internet in Ukraine *

\begin{tabular}{|c|c|c|c|c|c|}
\hline \multirow{2}{*}{ Indexes } & \multicolumn{5}{|c|}{ Years } \\
\hline & 2010 & 2015 & 2017 & 2018 & 2019 \\
\hline 1._Number of enterprises that used computers, units & 50846 & 41597 & 40327 & 44133 & 44532 \\
\hline $\begin{array}{l}\text { 2.-Proportion of the average number of employees who used a } \\
\text { computer, } \% \text { of the total number of employees }\end{array}$ & 28,2 & 34,5 & 34,9 & 32,8 & 34,3 \\
\hline $\begin{array}{l}\text { 3. Number of enterprises that had access to the Internet, units } \\
\text { of them used the Internet for: }\end{array}$ & 43847 & 40747 & 39582 & 43303 & 43785 \\
\hline - sending or receiving e-mails & 30976 & 37331 & 38929 & 42733 & 43278 \\
\hline- in $\%$ to the total & 70,65 & 91,62 & 98,35 & 98,68 & 98,84 \\
\hline $\begin{array}{l}\text { - Making phone calls using Internet / VoIP or video confer- } \\
\text { encing }\end{array}$ & 10348 & 8568 & 12048 & 13673 & 14450 \\
\hline- in $\%$ to the total & 23,60 & 21,03 & 30,44 & 31,58 & 33,00 \\
\hline - obtaining information about goods and services & 19519 & 22775 & 34663 & 38468 & 39066 \\
\hline- in $\%$ to the total & 44,52 & 55,89 & 87,57 & 88,83 & 89,22 \\
\hline - Using instant messaging and bulletin board & - & - & 18704 & 21167 & 21654 \\
\hline- in $\%$ to the total & - & - & 47,25 & 48,88 & 49,46 \\
\hline - obtaining information from public authorities & 10067 & 21397 & 31571 & 35034 & 35671 \\
\hline- in $\%$ to the total & 79,76 & 79,76 & 79,76 & 80,90 & 81,47 \\
\hline $\begin{array}{l}\text { - carrying out various operations with public authorities } \\
\text { (except for obtaining information) }\end{array}$ & - & - & 20158 & 22413 & 23361 \\
\hline -in $\%$ to the total & - & - & 50,93 & 51,76 & 53,35 \\
\hline - carrying out banking operations & 35750 & 38276 & 38227 & 42070 & 42754 \\
\hline- in $\%$ to the total & 81,53 & 93,94 & 96,58 & 97,15 & 97,65 \\
\hline - accessing to other financial services & 3779 & 7172 & 15535 & 17612 & 18147 \\
\hline- in $\%$ to the total & 8,62 & 17,60 & 39,25 & 40,67 & 41,45 \\
\hline
\end{tabular}

* Calculated on the basis of sources [8]

Also, analyzing the use of the Internet, it should be noted that since 2010 to the present, the share is growing accordingly. And it is mostly used for sending or receiving e-mails (70,65\%-98,84\%), receiving information about goods and services $(44,52 \%-89,22)$, banking operations $(81,53 \%-97,65 \%)$. Examining 
the number of companies that used computers by industry, we note that the largest number of companies are manufacturing companies and wholesale and retail trade.

The world without wires today is not a fantasy but a reality, even a daily reality. It should be noted that the Internet of Things is able to penetrate into all nooks and crannies that are inaccessible and often invisible world, which goes far beyond the action of the organs of sight, hearing and consciousness. It creates new types of networks and systems, completely different routes for information and knowledge. We should be note that the "cloud" is a new tool for providing and receiving information services. This model promises to reduce operating and capital costs. Examining the use of cloud computing services of Ukrainian enterprises, we observe that at Ukrainian enterprises cloud computing services are used for financial or accounting applications up to $58 \%$, for e-mail up to $57 \%$, for office software up to $46 \%$.

Thus, today it is impossible to imagine an enterprise that does not include non-current assets on the balance sheet of fixed assets (computers) and intangible assets (software).

It should be noted that to conduct business, you need accounting software to accurately manage the financial condition of the enterprise. Of course, the chosen software should be directly related to the size and scope of the business. There are more accounting software options than ever, with different price ranges to suit any budget, such as Intuit QuickBooks Online, FreshBooks, Pabbly, Wave, Sage 50cloud, Xero, Zoho Books, GoDaddy Bookkeeping, Kashoo , AccountEdge Pro, OneUp, Tipalti, OnPay, NetSuite ERP, FreeAgent, Accounting Seed, Sunrise by Lendio, Zipbooks, Holded [8]. Thus, table 3 shows 10 accounting programs for small business used abroad.

\section{TOP-10 accounting programs for small business *}

\begin{tabular}{|c|c|}
\hline Name of the program & Characteristic \\
\hline AccountEdge Pro & $\begin{array}{l}\text { Has all the accounting functions that grow the needs of the business, combining the reliabil- } \\
\text { ity of the desktop application and the flexibility of the mobile application for those who need } \\
\text { constant access. }\end{array}$ \\
\hline FreshBooks & $\begin{array}{l}\text { Offers invoicing, time and cost tracking, easy project management and a wide range of gen- } \\
\text { eral accounting programs - all in one easy-to-use desktop and mobile interface. }\end{array}$ \\
\hline $\begin{array}{l}\text { Sage 50cloud Ac- } \\
\text { counting }\end{array}$ & $\begin{array}{l}\text { Is a multi-functional accounting platform with tools for sales tracking, reporting, invoicing } \\
\text { and payment processing, and managing suppliers, customers, and employees. }\end{array}$ \\
\hline QuickBooks Desktop & $\begin{array}{l}\text { New features include: } \\
\text { Improved navigation system; Extended help; Automatic payment reminders are sent to } \\
\text { overdue customers; Ability to consolidate invoices in one email; Invoicing }\end{array}$ \\
\hline Zoho Books & $\begin{array}{l}\text { Available for even the smallest budget, Zoho Books includes a robust inventory manage- } \\
\text { ment feature and provides new users with step-by-step instructions on everything from gen- } \\
\text { eral setup to invoicing, making it easy to set up and run your new business quickly. }\end{array}$ \\
\hline AccountingSuite & $\begin{array}{l}\text { Offers features that small businesses expect from any software, including cloud availability } \\
\text { and reliable accounting capabilities. Banking links are also offered in AccountingSuite, } \\
\text { which allows the program to connect to more than } 9,000 \text { financial institutions. }\end{array}$ \\
\hline OneUp & $\begin{array}{l}\text { Suitable for private entrepreneurs and freelancers, thanks to its reliable inventory manage- } \\
\text { ment module, OneUp is a great option for retailers. OneUp is also suitable for a growing } \\
\text { business with pricing based solely on the number of users, not on functions, at its own tariff } \\
\text { for one user, including the same functions as the "Unlimited" tariff plan. }\end{array}$ \\
\hline QuickBooks Online & $\begin{array}{l}\text { Designed exclusively for small businesses, QuickBooks Online offers easy access anytime, } \\
\text { anywhere, which was lacking in their more reliable desktop version. QuickBooks Online, } \\
\text { which is suitable for small and growing businesses, is often compared to FreshBooks. It in- } \\
\text { tegrates with hundreds of third-party applications, making the application suitable for all } \\
\text { types of business. Features available in all plans include an Internet banking connection, the } \\
\text { ability to receive reports for preparing expense reports, and a good cost management feature }\end{array}$ \\
\hline Xero & $\begin{array}{l}\text { Is an online accounting software that offers the convenience of running your business from } \\
\text { anywhere. It is designed for a small business owner who does not want to spend a lot of time } \\
\text { studying accounting, but wants to be on top of business results. Xero works great for a varie- } \\
\text { ty of niche markets, including retail, IT, legal, e-commerce and startups, and its ability to } \\
\text { deal with a variety of currencies makes it suitable if you do business around the world. Xero } \\
\text { offers dual-entry accounting, with a default chart of accounts that can be customized as } \\
\text { needed, included in the program. Periodic journal entries are available in the app, and you } \\
\text { can easily connect your bank accounts to Xero to automatically import all banking transac- } \\
\text { tions. }\end{array}$ \\
\hline $\begin{array}{l}\text { Sage Business Cloud } \\
\text { Accounting }\end{array}$ & $\begin{array}{l}\text { Suitable for private entrepreneurs and freelancers, Sage Business Cloud Accounting also } \\
\text { includes robust inventory management, making it a good option for retailers, especially } \\
\text { online retailers. Sage Business Cloud Accounting includes numerous sales features, such as } \\
\text { quotes and estimates, credit notes, and the ability to customize invoices as needed. }\end{array}$ \\
\hline
\end{tabular}

* Systematized on the basis of sources [9] 
Thus, accounting software is the software used by companies to track financial statements, cash flows, invoicing, bank accounts and purchase orders. These systems sometimes have special functionality for certain sizes of business, self-employed or freelancers, small businesses or businesses. Because the accounting solution serves an important business process, it is often a central component of an organization's corporate resource planning (ERP) system.

Conclusions and prospects of the further investigations. Thus, there are information systems that support group solutions, and among them - electronic meeting systems. Therefore, at a new level is the organization of information and communication process with the use of new information technologies in management, as well as automation of routine methods of computer information processing.

As a result of the study it was determined that at the level of management the following tasks are solved:

- processing of data on transactions made by the firm;
- checking reports on the state of affairs at the enterprise;

- document management for inquiries and answers, etc.

It has been determined that the use of information and communication technologies has a significant impact on the viability and competitiveness of the enterprise. Therefore, the management should see the prospects of financial and economic development of the organization, taking into account the contribution that can be made by automated information technology.

It can be noted that IT affects all business processes, and accounting is no exception. The accounting system is very important in its purpose and functions in the organization - collection and accounting of data and information on events that have economic impact on the organization and maintenance, processing and transmission of information to internal and external stakeholders, providing financial information for decision-making in the organization. Thus, accounting procedures change when most information exists only in electronic form, and this leads to the development of different methods.

\section{References}

1. Hryn, V. P. (2019). Sutnist ta vydy oblikovoho informatsiinoho prostoru. Ekonomika, Upravlinnia Ta Administruvannia, (4(90), 141-147. doi: 10.26642/ema-2019-4(90)-141-147 universitet.

2. Vahrushina, M. A. (Ed.). (2017). Buhgalterskiy uchet $v$ sovremennyih biznes-strukturah. Finansovyiy

3. Benko, M. M. (2010). Informatsiini systemy i tekhnolohii v bukhhalterskomu obliku. Kyiv. nats. torh.ekon. un-t.

4. Budko, O. V. (2013). Finansova zvitnist yak dzherelo informatsii dlia pryiniattia upravlinskykh rishen. Efektyvna ekonomika, (1). http://www.economy.nayka.com.ua/?op=1\&z=1721

5. Hudz, O. Ye. Suchasni informatsiino-komunikatsiini tekhnolohii $v$ upravlinni pidpryiemstv. http://www.dut.edu.ua/uploads/p_1010_70172914.pdf

6. Reva, O. M., \& Smirnov, O. O. (2010). Pidvyshchennia konkurentospromozhnosti pidpryiemstva na osnovi zaprovadzhennia informatsiinykh system i tekhnolohii. Naukovi pratsi Kirovohradskoho natsionalnoho tekhnichnoho universytetu. Ekonomichni nauky, (18(1), 42-47. 1bullettext.htm

7. The Role of Information Systems in Business Today. https://paginas.fe.up.pt/ als/mis10e/ch1/chpt1-

8. Vykorystannia informatsiino-komunikatsiinykh tekhnolohii na pidpryiemstvakh u 2010, 2015, 2017, 2018 2019 rokakh. Derzhavna sluzhba statystyky Ukrainy. http://www.ukrstat.gov.ua

9. Mary Girsch-Bock The Top 10 Accounting Software for Small Businesses in 2021. https://www.fool.com/the-blueprint/accounting-software-reviews/

10. Fatenok-Tkachuk, A. (2015). Orhanizatsiia oblikovo-analitychnoho zabezpechennia protsesu formuvannia stratehii rozvytku pidpryiemstva. Ekonomichnyi chasopys Skhidnoievropeiskoho natsionalnoho universytetu imeni Lesi Ukrainky, (2), 82-88. doi: 10.29038/2411-4014-2015-02-82-88 
Маркова Т.Д.

кандидат економічних наук, доцент кафредра обліку та аудиту

E-mail: markova.tetiana17@gmail.com ORCID ID: 0000-0002-9437-2635

Пчелянська Г.Б.

старший викладач кафедра обліку та аудиту

E-mail: gaya od@ukr.net ORCID ID: 0000-0003-0944-986X

\author{
Мельник Ю.М. \\ доктор економічних наук, професор \\ кафредра обліку та аудиту \\ E-mail:9701080@ukr.net \\ ORCID ID: 0000-0003-2307-1592
}

тіллоєв C.

Студент 5 курсу факультету економіки, бізнесу і контролю Одеська національна академія харчових технологій вул. Канатна 112, м. Одеса, Україна, 65039

E-mail: tilloievsanzhar@ukr.net ORCID ID: 0000-0002-3340-121X

\section{ОСОБЛИВОСТІ УПРАВЛІНСЬКИХ ІНФОРМАЦІЙНИХ СИСТЕМ I ТЕХНОЛОГІЙ В ОРГАНІЗАЦІї АВТОМАТИЗОВАНОГО ОБЛІКОВО- АНАЛІТИЧНОГО ПРОЦЕСУ НА ПІДПРИЕМСТВІ}

У статті обґрунтовується роль інформаційних систем і технологій в процесі управління обліково-аналітичного процесу на підприємстві, оскільки 80 \% необхідної інформації накопичуються й формуються в системі бухгалтерського обліку та звітності. Перелічені переваги та недоліки від застосування інформаційних систем і технологій. Визначено, що дотримання якості інформаційного забезпечення можливе за умови дотримання принципів системність, комплексність, науковість, достовірність, доцільність, ефективність, пріоритетність, прозорість та цільове спрямування. Наведені прикладні програми вітчизняного та зарубіжного досвіду, які використовується підприємствами для відстеження фінансової звітності, руху грошових коштів, виставлення рахунків, банківських рахунків та замовлень на придбання, а також їх характеристика. Визначено, що впровадження комп'ютерної техніки та Інтернету у повсякденні процеси підприємств зумовлено поширенням та необхідністю обробки величезних масивів інформації у найкоротші терміни та її миттєву передачу на великі відстані. Проведена оцінка використання комп'ютерів на підприємстві та напрями використання мережі Інтернет в Україні. Проаналізувавши напрями використання мережі Інтернет, визначено, що починаючи з 2010 року до теперішнього часу частка відповідно росте. I найбільше використовують Інтернет для надсилання чи отримання повідомлень електронною поштою (70,65\%-98,84\%), отримання інформації про товари та послуги (44,52\%-89,22), здійснення банківських операцій (81,53\%97,65\%). Дослідження кількості підприємств, які використовували комп'ютери у розрізі галузей, визначено, що найбільша кількість підприємств - це є підприємства переробної промисловості та оптова й роздрібна торгівля. Визначено, що інвестиції у інформаційні технології окупаються та дозволяють досягти таких ефективних та стратегічних бізнес-цілей як операційну досконалість, нових продуктів та бізнес-моделей, дотримання конфіденційності клієнтів, покращене прийняття рішень, безліч конкурентних переваг, виживання та адаптування до ринкових сучасних вимог.

Ключові слова: інформаційні системи і технології, автоматизоване робоче місце, облік, аналіз, підприємство.

\section{Література}

1. Гринь В.П. Сутність та види облікового інформаційного простору // Економіка, управління та адміністрування. 2019. № 4 (90). С. 141-147. doi: 10.26642/ema-2019-4(90)-141-147

2. Бухгалтерский учет в современных бизнес-структурах: монография / под ред. М.А. Вахрушиной. М. : Финансовый университет, 2017. 235 с.

3. Бенько М.М. Інформаційні системи і технології в бухгалтерському обліку: монографія. К. : Київ. нац. торг.-екон. ун-т, 2010. 336 с.

4. Будько О.В Фінансова звітність як джерело інформації для прийняття управлінських рішень // Ефективна економіка. 2013. № 1 URL: www. economy.nayka.com.ua/?op=1\&z=1721(дата звернення 15.05.2021)

5. Гудзь О.С. Сучасні інформаційно-комунікаційні технології в управлінні підприємств. URL: http://www.dut.edu.ua/uploads/p_1010_70172914.pdf(дата звернення 15.04.2021)

6. Рева О.М., Смірнов О.О. Підвищення конкурентоспроможності підприємства на основі запровадження інформаційних систем і технологій // Наукові праці Кіровоградського національного технічного університету. Економічні науки. 2010. Вип. 18(1). С. 42-47

7. The Role of Information Systems in Business Today. URL: https://paginas.fe.up.pt/ als/mis10e/ch1/chpt11bullettext.htm (дата звернення 17.04.2021)

8. Використання інформаційно-комунікаційних технологій на підприємствах у 2010, 2015, 2017, 20182019 роках. Державна служба статистики України. URL: http://www.ukrstat.gov.ua (дата звернення 16.04.2021) 
9. Mary Girsch-Bock The Top 10 Accounting Software for Small Businesses in 2021. URL: https://www.fool.com/the-blueprint/accounting-software-reviews/(дата звернення 16.04.2021)

10. Фатенок-Ткачук А. Організація обліково-аналітичного забезпечення процесу формування стратегії розвитку підприємства // Економічний часопис Східноєвропейського національного університету імені Лесі Українки. 2015. №2. С.82-88. doi: 10.29038/2411-4014-2015-02-82-88

Стаття надійшла 25.04.2021

Стаття прийнята до друку 10.05.2021

Доступно в мережі Internet 21.07.2021

Цитування згідно ДСТУ 8302:2015

Markova T., Pchelianska G., Melnyk Yu., Tilloyev S. Features of management information systems and technologies in the organization of the automated accounting and analytical process at the enterprise // Food Industry Economics. 2021. Vol.13, Issue 2. P. 71-79. doi: 10.15673/fie.v13i2.2042

Cite as APA style citation

Markova, T., Pchelianska, G., Melnyk, Yu., \& Tilloyev, S. (2021). Features of management information systems and technologies in the organization of the automated accounting and analytical process at the enterprise. Food Industry Economics, 13(2), 71-79. doi: 10.15673/fie.v13i2.2042 